\title{
LIFE AFTER NATURAL DISASTER: THE CASE OF RESETTLEMENT POLICY IN PAGERJURANG, YOGYAKARTA
}

\author{
${ }^{1}$ M. Rizki Pratama, ${ }^{2}$ Abd. Qadir Muslim, ${ }^{3}$ Bayu Amengku Praja, ${ }^{4}$ Bayu Indra Pratama, ${ }^{5}$ Endry \\ Putra \\ 1,2,3,4,5 Jurusan Administrasi Publik, Fakultas IImu Administrasi, \\ Universitas Brawijya \\ pratamarizkim@ub.ac.id \\ Malang, 65145, Indonesia
}

\begin{abstract}
Public policy in managing natural disasters in Indonesia has not yet optimal. Nonetheless, there emerge programs to deal with natural disasters as the case of the 2010 Mount Merapi eruption. The government relocated the survivors using the Rekompak (Community-Based Rehabilitation and Reconstruction of Society and Settlement) program. Researcher employs interpretative approaches to understanding the reality which experienced by local inhabitants. Rekompak finished in 2014 at Pagerjurang, but this study uncover the side of the survivors who have moved to the new residential area. As the final statement, this study presents that moving residents' residences is not only a matter of physical displacement, but other conditions might hinder the resilience of local inhabitants such as changes in economic and socio-cultural conditions.
\end{abstract}

Keywords: Mount Merapi; Natural disaster management; Public policy; Rekompak; Relocation

\begin{abstract}
Abstrak
Kebijakan publik dalam mengelola bencana alam di Indonesia belum optimal. Meskipun demikian, muncul program untuk menangani bencana alam seperti kasus letusan Gunung Merapi 2010. Pemerintah merelokasi para penyintas dengan menggunakan program Rekompak (Rehabilitasi dan Rekonstruksi Berbasis Masyarakat dan Pemukiman). Peneliti menggunakan pendekatan interpretatif untuk memahami realitas yang dialami oleh penduduk lokal. Rekompak selesai pada 2014 di Pagerjurang, tetapi penelitian ini mengungkap sisi para penyintas yang telah pindah ke daerah perumahan baru. Sebagai pernyataan terakhir, penelitian ini menunjukkan bahwa memindahkan tempat tinggal warga bukan hanya masalah perpindahan fisik, tetapi kondisi lain mungkin menghambat resiliensi penduduk lokal seperti perubahan kondisi ekonomi dan sosial budaya.
\end{abstract}

Kata Kunci: Kebijakan publik; Manajemen bencana alam, Rekompak, Relokasi, Gunung Merapi

Open Access at: http://ojs.uho.ac.id/index.php/PUBLICUHO/index

Journal Publicuho is licensed under a Creative Commons Attribution 4.0 International License. 


\section{INTRODUCTION}

Government policy in providing the best contribution to victims of natural disasters can be said to be less optimal. A closer look in responsiveness, coordination, and participation of post-disaster should be able to minimize all the negative impacts of natural disasters (Sadat, 2016; Bakkour et al., 2013; Kurniawan et al., 2013 ). Therefore, the government must be able to improve public policies after natural disasters, because victims of natural disasters are indeed not able to develop by the characteristics of people who return to health if the government's post-disaster problems are not addressed.

Many things have happened, such as lack of comprehensive policies, lack of community participation to corruption, in addition in some cases the relocation policies carried out by the government to the community tend to bring many conflicts. For example, regarding the post-disaster rehabilitation and reconstruction policy, the problems that arise later are the limited funding sources and the number of actors and parties involved with various interests and make the program less integrated and efficient (Soesilowati, 2010). In the case of natural disasters in Indonesia there are still many adverse effects of post-disaster relocation that have fatal consequences for society such as psychological or trauma impacts and the economy which leads to poverty.

Here the Rekompak Program (Community-Based Rehabilitation and Reconstruction of Society and Settlements) is an initiative carried out by the government to minimize the negative impacts of natural disasters, especially when relocation of people to safer places. It is imperative to recognize that relocation policies not only move settlements and physical environments but also move the lives of citizens themselves. Moving life is a crucial point of the Rekompak Program so that the role of the community that is preferred or who should have the ability to help themselves through a little assistance from the government. Rekompak is now being developed on a community-based basis, but so far not all Rekompak-based relocations have been able to guarantee a better future for the community. Further can be quoted that:

Rekompak is the name of a community-based approach for large scale reconstruction of homes and community infrastructure pioneered in Indonesia by the MDF (Multi-Donor Fund) and JRF (Java Reconstruction Fund). In Indonesian, Rekompak conveys the meaning of "reunion" -- to increase cohesiveness and become solid again. Rekompak embodies the spirit of the community based approach and captures the essence of the project, the focus of which has been to rebuild lives while rebuilding communities (World Bank, 2012).

The report shows the Rekompak values that are very basic to not only move the population but also to maintain the value of their lives so as not to be damaged which can worsen their condition. 
Journal Publicuho

ISSN 2621-1351 (online), ISSN 2685-0729 (print)

Volume 3 Number 3 (August-October), (2020) pp.279-288

Open Access at: http://ojs.uho.ac.id/index.php/PUBLICUHO/index

This study tries to understand the condition of the community after relocation in a permanent residence (Huntap) Pagerjurang, Sleman, Yogyakarta as one of the results of the Rekompak program that has been completed. Rekompak can be considered successful in moving the population without conflict which means that it is due to quality development (Mei et al., 2016) and community-based participation (Bawole, 2015). However, this study is also expected to see on the other side. That the relocation of the population due to disasters always brings various dilemmatic effects, in addition to being able to save the lives of residents with new locations with minimal disasters as well as to kill the economic potential of people who have lost their livelihoods due to natural disasters. This study looks at how far the impact of relocation is based on the perspective of local inhabitants as survivors of Mount Merapi's natural disasters.

\section{METHODOLOGY}

Researchers comprehend the reality of people's lives after relocation based on stories from survivors of natural disasters. To understand this reality researchers use an inductive approach without prioritizing expectations that have been previously suspected (Patton, 2009) or can also be called using the constructivism approach or interpretivism (Creswell, 2010). Practically researchers collect data by field observations and conduct in-depth interviews with survivors. All observations and interviews are analyzed through three stages: data reduction, data presentation, and conclusion/verification (Miles \& Huberman, 1992). In the end, it produced a general topic of data in the form of the lives of residents in relocation that were detailed both on the physical, economic and socio-cultural environment.

\section{RESULT AND DISCUSSION}

\section{Rekompak's Overview In Pagerjurang Permanent Shelter}

Fixed shelter Pagerjurang is a place of the relocation of residents who were directly affected by the eruption of Mount Merapi in 2010. Local inhabitants must go for relocation because their area or village where they lived was unable to be occupied anymore due to severely damaged. Also that it was classified in the zone the danger of Merapi eruption is therefore inevitably they all have to be relocated. Huntap Pagerjurang itself is located in Kepuharjo Village, Cangkringan Subdistrict, Sleman Regency Special Region of Yogyakarta which has an area of $49,665 \mathrm{~m}^{2}$ and has been filled with 301 families who occupy 301 houses (Ministry of Public Works, 2013). Started construction in 2011 and has been occupied by residents at the end of 2012, development is considered complete in 2014.

\section{Life in Post-Relocation}

Various interesting findings can be presented through the following presentation, which will be divided into three main parts, namely first, physical environment, second, economy and the last is social and cultural. Through this brief presentation, at least a small depth of life 
in the post-Merapi eruption was found, which of course they must continue to live and live a better future. The Rekompak approach is community-based so that the government conducts policies based on decisions with the community or together with the community. According to Friedmann (1979) said that the forms of community policy could be done through several approaches, namely the community development based approach that deals with efforts to help the community to support themselves and community service (Soesilowati, 2010). Furthermore, some findings can be presented as follows:

\section{a. Physical Environmental Conditions}

First, related to the physical environment. Development in Huntap is a development that is based on the desire to integrate the physical environment with the social community so that a better life for the community is expected to emerge, even though the community is involved there are still some deficiencies desired by residents.

"The yard is too small for the family cage; there is only for the cow pen together so it cannot raise other livestock such as super Javanese chickens." (Interview X1)

The government does not provide a large house yard in every house in the village apart from the limited land because of land efficiency; this is very important considering a large number of residents and different interests. Therefore, there must be uniformity to get feeling with citizens and no social jealousy. In the construction of places of worship in this case also still not by the wishes of citizens.

"In the gig, there is only one mosque in the gig, and according to him there is still less at least there must be a prayer room per hamlet." (Interview X2)

The above is also related to the existence of religious leaders who used to have their power in their places of worship so that it will bring up a culture that is typical and obeyed by the people. After moving to Huntap, the power can be notarized because there is only one mosque in Huntap. Become a consideration, but the limited land can be made a reasonable reason, with a limited amount, the use of land must be efficient, and there are already large mosques that can accommodate citizens' worship.

"For treatment, the Puskesmas is still outside, there is only a clinic that is handled by a midwife/mantri and still stays at the residents' house, or there is no permanent building. "( Interview X3)

Health facilities at Huntap itself are not so good. There are no clinics that can be relied upon to serve the health of the residents. The severity of there is no doctor, in fact this also happens not only in Huntap but also on the average health services in the village, there should be doctors who enter the village because not all regions close to community health 
centers even in Huntap there are only nurses and midwives so that health services are not optimal.

"The water here is good, bro, all the way to use the pipeline is the problem." (Interview X4)

As an area with permanent buildings and prepared for long-term settlement, clear clean water facilities that flow are highly needed, in this case, the government has provided quite well proven that there is no significant problem in the provision of clean water for households in the hunt and according to the flowing water 24 hours a day. The other physical aspects, Huntap's physical building became one of the focuses.

"Buildings in the huntap are splendid compared to other hamlets that live in." (Interview X5)

From the above opinion, it can be judged that residents are satisfied with the quality of the building in Huntap. They were comparing it to other places, some cases in other disaster areas often buildings for disaster victims have poor quality because of mismanagement from the beginning, for example, the residents are not involved in the development process, and of course, there are pieces of people here and there so that the building has poor quality.

"Government assistance is only 30 million; others add themselves if they want to be good, for example, to paint and add windows and doors. Assistance has been in the form of material, the contractor with all, residents who determine, prices are the same, the material has also been examined by themselves. "(Interview X6)

The government does provide Rp. 30 million assistance for each affected family, this amount calculation is only optimal for building a simple house. Indeed the house produced will certainly not be able to match the homes of previous residents with large yards and quite large houses. The residents themselves try to improve their respective homes to suit their desires, at least by giving paint and home decorations that are different from the original or standard so that it is more comfortable to live even at their own expense.

"Public facilities are added, such as a prayer house, clinic with a doctor, poskamling (local community security), and public restroom. Street lighting is also not maximized; the front entrance gate also has no lighting, there should be lights every time, especially at the intersection of entering the building. "(Interview X7)

Residents still feel dissatisfied with the construction of public facilities around Huntap. The public facilities are critical because it supports the lives of the citizens themselves so they can return to ordinary inhabitants. Small things are often overlooked sometimes, for example after the construction is completed it is realized that there is no optimal street lighting in the Huntap area so that at night the Huntap area appears dark and very very dangerous if used by passing the vehicle by residents. From various quotes and a little elaboration above at least, it will be understood how the physical environment in Huntap Pagerjuang. 


\section{b. Economic Conditions}

Second, economic conditions. In the economic structure, it is often the people who are victims because nature is trapped regarding poverty because of their disadvantages. They automatically lose their livelihoods and even drop their production tools. The drawback is also because the victims do not have sufficient funds to buy post-disaster services and goods. The results have affected the disruption of production flows, services, economic inputs, and infrastructure support (Wimbardana, 2010). At least in Huntap, fewer people still get attention from the government and various other organizations so that their economic conditions will not change much, they should even be improved. Most residents still have the same livelihood when before the disaster, but the results cannot be as they were before and some others start working in other sectors.

"The livelihoods of many people are still like before moving to the shelter, for example, farming, livestock, and sand or rock mining but the results are smaller because the location is now far away and a lot of lands is damaged. If the young people work a lot in building projects, they become builders or porters; others also start going to other businesses, such as selling in the market. "(Interview X8)

The people's livelihood is not much changed, but what happens is that when residents have to the much longer distances to return to their gardens or fields or mine sand and stone, Huntap's location is far enough to ensure the safety of the people if Merapi erupts, so huntap is in a safe radius. Especially for women who previously only worked in the kitchen so that they do not have the potential to develop the economy, there are now many groups of women who move to produce something because there is initiation from other parties:

"There was an effort to help from UGM Community Service Program to generate economic activities of the hamlet mothers in groups through training in making batik, bakpia telo, abon lele, etc. There is a kind of gallery for batik, seeing the nyating process. In the past, mothers did not have optimal economic activities, only at home or in the garden. "(Interview X9)

Initiation from external parties is essential because it is almost impossible if people close themselves and develop only around the knowledge they have, therefore training to raise the people's economy is very urgent to do. Residents do not have to go back to the slopes of Merapi to make a living but must be able to utilize the potential of the resources that are around them, when mothers were not able to do potential economic activities, but after they were trained, they could and continue. In addition to providing additional livelihoods, the government also gives cattle to every family in Huntap.

"The government has assisted in the form of one cow per household if people want it. If I am lazy myself, the problem is that it is difficult to find food, the time cannot be added to other work. "(Interview X10) 
In the case of giving cattle to be developed by residents, it turns out that not all residents receive it because of various problems. The problem due to the value of livestock that is quite expensive. It will cause the economic disparity between residents who refuse to give cattle. The government should also provide an alternative other than giving a cow. For example, by providing help to other livestock or directly with an asset that has the same value as a cow so residents can have many alternatives to improve their economics besides that if a variety of livelihoods arise, it will increase the resilience of the citizens themselves so that they do not depend on specific professions.

\section{c. Social and Cultural Conditions}

Third, social \& cultural conditions. The physical development carried out by moving the population has the potential to break the conflict. But what happened during the relocation, rehabilitation and reconstruction period can be remembered that almost no major conflict erupted, the process of moving people did not consume a lot of energy to deal with ethical conflicts with fellow citizens or with the government and various other organizations involved. In Huntap's social situation, now the sense of belonging to Huntap has been built, at least can be seen from the way they maintain Huntap's cleanliness with full awareness of each.

"The village's hygiene regulations are stringent, people remind each other, rubbish must be sorted, and there are garbage workers who take it once a week." (Interview X11)

Citizens uphold their own rules so that their common interests do not cause further problems. It is what characterizes the color of life in the village where the level of citizens' care is still quite high, reminding each other with their awareness. Thanks to the concept of rekompak which not only moves settlements but also the lives of citizens, at least one can learn that the social structure of villagers is not damaged and replaced by the characteristics of urban hedonists and individual suburban communities. Nonetheless, rural values

continue to emerge, which begin to change, such as the loss of night patrols and the habit of looking at neighbors, which leads to a shift towards individualistic values. Again, according to Turiman, the values

of togetherness are still active, with the existence of events with residents on a weekly basis to discuss specific issues with several other negative notes:

"Every village has a forum or community meeting once a week, usually discussing the problems of citizens, joint activities for a week, etc. If it does not come there will be social sanctions, nor do you understand anything if you live alone. But there is also something different here, starting from the night patrol is not there because it is considered safe. Let alone the sambang residents have almost no problem now the house is overlapping each other every day, I will find it, different from the previous time all have a large yard, it must be longer if sambang, many are said "(Interview X12) 
The social condition of the community remains almost the same as in the village where they were located, for example, it can be found that the function of social sanctions for citizens is still dominant. Every week they hold a kind of discussion per hamlet to solve problems or to keep a community activity when there are residents who do not come will undoubtedly be reprimanded by their fellow citizens even if it is necessary to go home directly. It is also done to find out the condition of the people if there are people who are sick or hit by problems so that residents can help each other and provide solutions.

\section{The Work of Policy in Post-Disaster}

The Rekompak program fosters new enthusiasm in the implementation of public policies seen from the level of conflict that occurs even though there are conflicts that at least do not arise massively and the average population has accepted the state of hunting and adapting well with all the limitations that exist. All kinds of shortcomings that occur must indeed be discussed together so that the problem is not more protracted as seen from the results of the analysis of the physical, social and cultural environment as well as the economy the results are not perfect but still better than the conditions of disaster victims in other regions.

"Residents are active in building new hamlets, through recompact cooperation with citizens. There is always talk with citizens during the development process. " (Interview X13)

A distinctive feature of community involvement in Rekompak makes the Rekompak program seen as carrying out a deliberative policy, where the people involved are asked to actively solve problems rather than the government or other actors who are only neutral parties. The community-based approach is very suitable with the principle of deliberative democracy that prioritizes the use of decision-making procedures that emphasize deliberation and problem solving through dialogue and exchange of experience between the parties and citizens (stakeholders). The goal is to reach consensus through deliberation based on the results of the discussion by considering various criteria (Mardiyanta, 2011). Also, this approach can overcome limitations along with a complete copy, such as the accelerator Denhardt \& Denhardt (2000) that policy networks are vital and need to be understood well because there is a fact that the government has financial and human limitations. Other actors that bring about collective decision making need to be involved so that the entire program is efficient and has high added value and can be enjoyed by residents (Soesilowati, 2010).

Regarding what policies have been carried out jointly by Rekompak. It provides meaningful input to the policymakers about how the policy actually works in the community, especially specifically on the policy of resettlement due to natural disasters, by providing access to the community itself so they can help themselves is more promising and provides 
Journal Publicuho

ISSN 2621-1351 (online), ISSN 2685-0729 (print)

Volume 3 Number 3 (August-October), (2020) pp.279-288

Open Access at: http://ojs.uho.ac.id/index.php/PUBLICUHO/index

mutual benefits than forcing them to do something they don't want to do. An essential point in the deliberative policy of the Rekompak model is that people are not trapped and should be avoided the emergence of structural conflict. Structural conflict originates from a feeling of helplessness and worthlessness that restrain the pace of reality when it reaches the achievement of the vision (Muluk, 2008). It means that people feel powerless as they think they do not have the strength and role in the common interest so they cannot do anything.

However, there are physical, economic and socio-cultural conditions that are shared responsibility for the rapid resilience of citizens. The changing physical environment contributes to the economic and socio-cultural changes of citizens. Residential locations that are far from livelihoods used to make residents look for other alternatives but have not been able to find economic conditions as before as before the disaster. Changes in citizens' values also need to be anticipated appropriately, such as a slight change in the value of community togetherness that shifts towards more individualist. Also, it is also necessary to monitor the current period when there is still a recovery period for the people in Huntap. In the recovery period, there was dissatisfaction of victims in rebuilding and creating differences in interests that caused horizontal and vertical conflicts. Political resources in the form of granting the right to express opinions and provide access to policymakers need to be done to avoid this. In many cases, efforts that can be done include the existence of individuals/organizations who can become neutral parties and mediate between individuals or groups at odds (Wimbardana et al., 2010). Therefore, the active role in maintaining Huntap's condition to remain conducive is still vital to be done so that they can return as a whole as a village community.

\section{CONCLUSION}

The Rekompak program in Pagerjurang can be concluded to have succeeded in moving people without conflict, but moving inhabitants is not only about the physical environment that is moving but also economic and socio-cultural conditions. Attention to the presence of citizens through community participation is valuable in Rekompak's program. But if financial problems such as changes in people's livelihoods and socio-cultural issues such as changes in the value of citizens are not managed properly then it will worsen the resilience of citizens after natural disasters, can gradually mean the potential for conflict as the final result of the program, the goal of program does not meet at the end. 


\section{REFERENCES}

Bakkour, Darine, Enjolras, Geoffroy, Kast, Robert, \& Thouret, Jean-Claude. (2013). the Adaptive Governance of Natural Disaster: Insight from the 2010 Mount Merapi Eruption in Indonesia. Lameta.

Bawole, Paulus. (2015). Community Based Resettlement Program for the Victims of Natural Disaster of Merapi Volcano Eruption. Tesa. 13(12). 114-127.

Creswell, John W. (2010). Research Design: Pendekatan Kualitatif, Kuantitatif, dan Mixed. Yogyakarta: Pustaka Pelajar.

Kurniawan, Lilik, Ascholani, Chasan, Irawan, Valentinus, Nurdin, Yusniar \& Wermasubun. (2013). Redefining Community Resilience in Indonesia. Indonesia National Agency for Disaster Management Research Report.

Mardiyanta, Antun. (2011). Kebijakan Publik Deliberatif: Relevansi dan Tantangan Implementasinya. Jurnal Masyarakat, Kebudayaan \& Politik. Vol. 24 (3).

Mei, E.T.W., Fajarwati, Alia, Hasanati, Surani, \& Sari, Ifa Meilyana. (2016). Resettlement Following the 2010 Merapi Volcano Eruption. Procedia-Social and Behavioral Sciences. 227. 361-369.

Miles, Matthew B \& Huberman, A Michael. (1992). Analisis Data Kualitatif. Jakarta: UI Press.

Muluk, M.R. Khairul. (2008). Knowledge Management: Kunci Sukses Inovasi Pemerintahan Daerah. Malang: Bayumedia.

Patton, Michael Quinn. (2009). Metode Evaluasi Kualitatif. Yogyakarta: Pustaka Pelajar.

Profil Huntap Karangkendal, Pagerjurang \& Batur. Satuan Kerja Rehabilitasi/Rekonstruksi Rumah Pasca Gempa Bumi DIY \& Jateng Ditjen Cipta Karya, Kementerian Pekerjaan Umum Maret 2013.

Sadat, Anwar. (2016). Efektivitas Kinerja Badan Penanggulangan Bencana Daerah dalam Pengurangan Resiko Bencana di Kota Bau-Bau. Jurnal IImu Pemerintahan. 1 (1). 1-18

Soesilowati, Ełty. (2010). Implementasi Integrasi Sektoral Program Kebijakan Rehabilitasi Aceh Singkil Pasca Bencana. Jurnal JEJAK. Vol. 3(2).

Wimbardana, Raditya, Saut Aritua Hasiholan Sagala, Alpian Angga Pratama \& Anastasia Ratna Wijayanti. (2014). Integrasi Rehabilitasi Sosio-Ekonomi Penduduk Setelah Gunung Merapi Tahun 2010 Terhadap Perencanaan Pemulihan. Bandung: Resilience Development Initiative (RDI).

World Bank. (2012). Rekompak: Rebuilding Indonesia's Communities After Disaster. Jakarta: The Secretariat of the Multi Donor Fund for Aceh and Nias and the Java Reconstruction Fund. 